\title{
PENGARUH EKSPEKTASI KEGIATAN USAHA TERHADAP INDEKS HARGA SAHAM GABUNGAN (Studi Kasus pada Bursa Efek Indonesia) ${ }^{1}$
}

\author{
Sumarsono \\ Program Studi Akuntansi, Fakultas Ekonomi, Universitas Kristen Maranatha Bandung \\ Email : ssumarsono70@yahoo.com
}

Safira Amalia Hapsari

Sekolah Bisnis \& Manajemen, Institut Tekhnologi Bandung

Email : safira.amalia@sbm-itb.ac.id

Submitted: May 12, 2017; Reviewed: May 13, 2017; Accepted: Feb 5, 2018

\begin{abstract}
The stock price reflect the performance of the company issuing the shares, not only at running time (t0) but also expectations for the future ( $t+$ ). The intrinsic value of the stock is investor's income in the form of dividends which depends on the income from business activities, so rating for effect of expectations of business activities can be seen as a reflection of expectations and risks to the performance of the company issuing the shares in the stock market which will affect stock prices, as reflected by Composite Stock Price Index (CSPI). This study aims to assess the effect of expectations of business activities on CSPI. The hypothesis is variables expectations of business activities individually or collectively affect the CSPI. Variable expectations of business activity expectation during the running time ( $t 0)$ on business activity, financial condition and easiness access to credit and expectations in the future ( $t+$ ) of business's situation on three months ahead ( $t+3)$ and six months ahead $(t+6)$. The study used survey data quarterly Kegiatan Dunia Usaha conducted by Bank Indonesia started from the first quarter of 2002 until the third quarter of 2016 and the data from Indonesia Stock Exchange Composite Stock Price Index after adjustment. Data taken from the publication of Bank Indonesia and Yahoo Finance. Hypothesis testing is using multiple regression The results of hypothesis testing found empirical evidence that the variable expectation of the company's financial condition of the present time and the expectation of business situation six months ahead have a significant positive effect on CSPI and business situation expectation over the next three months have a significant negative effect on CSPI. The variable of expectation of the current business activity and the expectation of easy access of credit have no significant effect to CSPI. All variable of expectation of business activity together have significant influence to CSPI.
\end{abstract}

Keywords: Expectation of Business Activity, Composite Stock Price Index (CSPI).

\footnotetext{
${ }^{1}$ Paper ini merupakan pengembangan penelitian dari paper penulis yang berjudul "Pengaruh Ekspektasi Konsumen Terhadap Indeks Harga Saham Gabungan di Bursa Efek Indonesia" yang dipresentasikan pada Forum Manajemen Indonesia (FMI) ke 6 di Fakultas Ekonomi dan Bisnis Universitas Sumatera Utara Medan pada tahun 2014. Paper yang sudah dipresentasikan di FMI ke 6 mengkaji pada perspektif "konsumen" dan paper ini mengkaji pada perspektif "produsen (perusahaan)".
} 


\section{PENDAHULUAN}

Dalam hipotesis pasar efisien ditekankan pentingnya informasi dalam investasi saham, karena kandungan infomasi tersebut akan mempengaruhi nilai saham. Nilai informasi yang berguna bagi pergerakan saham adalah infomasi yang mengandung perkiraan terhadap kinerja masa depan perusahaan.

Fenomena tersebut terjadi karena pasar saham mencerminkan ekspektasi masa depan terhadap kondisi perekonomian, investor melakukan penawaran harga ketika investor memperkirakan perusahaan akan mendapatkan keuntungan. Peningkatan harga saham menandakan bahwa investor menduga perekonomian akan tumbuh dengan cepat dan penurunan harga saham menandakan bahwa investor menduga akan terjadinya kelesuan pada perekonomian (Mankiw, 2007). Samuelson (1992) menyatakan, salah satu cara untuk menyampaikan mengenai teori yang mendasar tersebut adalah : investor tidak boleh menebak pasar secara salah. Investor dapat salah karena kurang/tidak akuratnya informasi.

Salah satu informasi ekspektasi yang berguna adalah informasi tentang ekspektasi usaha. Jika ekspektasi kegiatan usaha masa sekarang dan masa mendatang optimistik, perusahaan diekspektasikan dapat beroperasi dengan baik dan dapat menciptakan serta meningkatkan laba yang akhirnya membuat harga saham meningkat dan secara umum akan meningkatkan indeks harga saham gabungan. Demikian juga sebaliknya jika ekspektasi usaha kebalikannya, maka perusahaan diekspektasikan tidak dapat beroperasi dengan baik sehingga tidak akan tercipta laba atau terjadi penurunan laba sehingga membuat harga saham turun dan secara umum akan menurunkan indeks harga saham gabungan.

Penelitian Campbell dan Diebold (2007) menemukan bukti empiris bahwa kondisi ekspektasi bisnis berpengaruh terhadap abnormal return saham. Demikian juga dengan penelitian Pinho dan Madaleno (2011) menemukan bukti empiris bahwa kepercayaan bisnis berpengaruh terhadap evolusi pasar saham.

Memperhatikan uraian diatas, maka dapat dirumuskan tujuan penelitian ini adalah untuk mengetahui apakah terdapat pengaruh ekspektasi kegiatan usaha terhadap indeks harga saham gabungan di Bursa Efek Indonesia. Berdasarkan penelusuran pustaka penulis sampai dengan penelitian ini ditulis, penulis belum berhasil menemukan penelitian di Indonesia dengan tema pengaruh ekspektasi kegiatan usaha terhadap indeks harga saham gabungan. Memperhatikan hal tersebut maka hasil penelitian ini akan berguna sebagai salah satu referensi dalam kajian pasar modal di Indonesia.

\section{LANDASAN TEORI, KAJIAN EMPIRIS DAN PENGEMBANGAN HIPOTESIS Penilaian Dan Pergerakan Saham}

Harga saham mencerminkan ekspektasi masa mendatang dan hal tersebut menunjukkan bahwa investasi saham adalah future oriented business. Nilai suatu intrinsik suatu saham merupakan present value dari deviden-deviden yang akan diterima oleh pemodal di kemudian hari (Husnan, 2005). Brealey et al (2011) memodelkan nilai intriksi saham tersebut sebagai berikut :

$$
P=\sum_{t=1}^{\infty} \frac{C_{t}}{(1+r)^{t}}
$$

Dimana $\mathrm{P}$ adalah nilai intrisik saham atau fundamental value, $\mathrm{C}$ adalah aliran kas dimasa mendatang dan $\mathrm{r}$ adalah opportunity dari biaya modal.

Aliran kas yang bisa dipakai dalam penilaian saham adalah laba perusahaan. Dari sudut pandang investor yang membeli saham, aliran kas yang diterima investor adalah laba yang dibagikan dalam bentuk deviden (Tandelilin, 2010). Bolten dan Weigand (2005) dengan memperhatikan aliran deviden (laba dikurangi proporsi laba ditahan), persamaan 1 dapat dituliskan sebagai berikut :

$$
P_{t}=\frac{E_{\mathrm{t}+1}(1-\lambda)+C(1-\lambda)}{\left(1+r_{i}^{*}\right)}
$$

Dimana $\mathrm{P}$ adalah harga saham, E merupakan harapan laba perusahaan laba mendatang, $\lambda$ adalah tingkat retensi laba ditahan, $\mathrm{C}$ adalah konstan yang merupakan representative dari harapan total laba selama siklus bisnis sampai akhir siklus dan $\mathrm{r}^{*}$ adalah interest rate.

Aliran kas dimasa mendatang berupa pembayaran deviden yang diterima oleh investor berhubungan langsung dengan harapan kinerja perusahaan di masa mendatang. Harapan kinerja perusahaan masa mendatang disamping tergantung pada ekspektasi kondisi internal perusahaan juga tergantung dari ekspektasi dari investor terhadap lingkungan eksternal 
perusahaan baik di skala industry maupun skala lingkungan makro. Thompson et al (2012) menguraikan bahwa lingkungan skala industry adalah adanya produk pengganti, customer, pendatang baru, perusahaan pesaing dan pemasok sedangkan lingkungan makro perusahaan yaitu kondisi ekonomi secara umum, tekanan globalisasi, tekanan social, factor perkembangan teknologi, kebijakan politik dan peraturan perundang-undangan, lingkungan dan kependudukan.

Terkait dengan lingkungan internal dan eksternal perusahaan yang dapat dimanifestasikan menjadi dua variabel penentu nilai intriksik saham yaitu laba dan tingkat bunga, maka derivatif dari persamaan 2 dapat dituliskan menjadi :

$$
\frac{1}{P} \frac{d P}{d t}=\frac{1}{E+C} \frac{d E}{d t}-\frac{1}{\left(1+r^{*}\right)} \frac{d r}{d t}
$$

Dari persamaan diatas menunjukkan bahwa perubahan harga saham disebabkan oleh faktor perubahan relatif harapan laba dan tingkat bunga (tingkat pengembalian yang disyaratkan pasar). Tabel I dan Gambar I menggambarkan fenomena dari harga saham sehubungan dengan perubahan laba dan tingkat bunga.

Ketika laba naik $(\mathrm{dE} / \mathrm{dt}>0)$ dan tingkat bunga turun $(\mathrm{dr} / \mathrm{dt}<0)$ harga saham akan naik $(\mathrm{dP} / \mathrm{dt}>0)$ hal tersebut ditunjukan dalam periode A dalam Gambar I.

Tabel 1. Ringkasan pengaruh Perekonomian dan Suku Bunga Terhadap Harga Saham

\begin{tabular}{ccccc}
\hline $\begin{array}{c}\text { Perubahan } \\
\text { dE/dt }\end{array}$ & dr/dt & Dan & $\begin{array}{c}\text { Implikasi } \\
\text { dP/dt }\end{array}$ & $\begin{array}{c}\text { Efek } \\
\text { Poisis Gambar I }\end{array}$ \\
\hline+ & - & & + & $\mathrm{A}$ \\
- & + & & - & $\mathrm{B}$ \\
+ & + & $(\mathrm{dE} / \mathrm{dt})>(\mathrm{dr} / \mathrm{dt})(1+\mathrm{r})(\mathrm{E}+\mathrm{C})$ & + & $\mathrm{C}$ \\
+ & + & $(\mathrm{dr} / \mathrm{dt})>(\mathrm{dE} / \mathrm{dt}) /[(\mathrm{E}+\mathrm{C})(1+\mathrm{r})]$ & - & $\mathrm{D}$ \\
- & - & $(\mathrm{dr} / \mathrm{dt})>(\mathrm{dE} / \mathrm{dt}) /(\mathrm{E}+\mathrm{C})(1+\mathrm{r})]$ & + & $\mathrm{E}$ \\
- & - & $(\mathrm{dE} / \mathrm{dt})>(\mathrm{dr} / \mathrm{dt})(1+\mathrm{r})(\mathrm{E}+\mathrm{C})$ & - & $\mathrm{F}$ \\
\hline
\end{tabular}

Sumber : Bolten dan Weigand (2005)

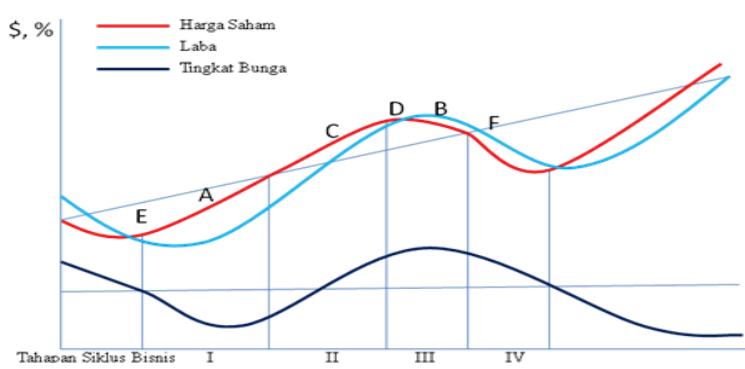

Gambar 1. Harga Saham, Laba dan Tingkat Bunga Setiap Kondisi Perekonomian Sumber : Bolten dan Weigand (2005)
Ketika laba diprediksi turun $(\mathrm{dE} / \mathrm{dt}<$ $0)$ tetapi tingkat bunga naik $(\mathrm{dr} / \mathrm{dt}>0)$ maka harga saham akan turun $(\mathrm{dP} / \mathrm{dt}<0)$ hal tersebut ditunjukan dalam periode $\mathrm{B}$ dalam Gambar I. Ketika laba diprediksi naik (dE/dt $>0)$ dan tingkat bunga naik $(\mathrm{dr} / \mathrm{dt}>0)$ secara umum harga saham akan naik atau turun. Jika dE/dt lebih besar daripada $(\mathrm{dr} / \mathrm{dt})(1+\mathrm{r})(\mathrm{E}+\mathrm{C})$, ekspektasi kenaikan laba lebih besar dibandingkan dengan ekspektasi dampak negatif kenaikan suku bunga, maka harga saham akan naik hal tersebut ditunjukan dalam periode $\mathrm{C}$ dalam Gambar I. Jika dr/dt lebih besar daripada $(\mathrm{dE} / \mathrm{dt})(\mathrm{E}+\mathrm{C})(1+\mathrm{r})$, kenaikan suku bunga lebih kuat membawa dampak negatif dan menyebabkan harga saham turun, hal tersebut ditunjukan dalam periode $\mathrm{D}$ dalam Gambar I. Ketika keduanya dr/dt dan DE/dt $<$ 0, ekspektasi laba membawa dampak negatif pada pasar saham tetapi tingkat bunga akan membawa dampak positif, namun secara umum harga saham dapat naik atau turun. Jika $(\mathrm{dr} / \mathrm{dt}) \quad>$ $(\mathrm{dE} / \mathrm{dt}) /[(\mathrm{E}+\mathrm{C})(1+\mathrm{r})]$ dampak dari turunnya tingkat bunga lebih kuat maka harga saham akan naik, hal tersebut ditunjukan dalam periode E dalam Gambar I. Jika (dE/dt) > $(\mathrm{dr} / \mathrm{dt})(1+\mathrm{r})(\mathrm{E}+\mathrm{C})$ penurunan pada ekspektasi laba lebih kuat berdampak maka harga saham akan turun, hal tersebut ditunjukan dalam periode F dalam Gambar I. Skenario akhir jika terjadi $(\mathrm{dE} / \mathrm{dt}) /(\mathrm{E}+\mathrm{C})=$ $(\mathrm{dr} / \mathrm{dt})(1+\mathrm{r})$, maka pasar saham pada posisi puncak (peak) atau bawah (trough) tergantung perubahan nilai yang mendahului. Jika kondisi di pasar puncak (peak) maka harga akan naik dan jika harga turun maka pasar akan turun.

Informasi mengenai kinerja pasar saham diringkas dalam suatu indeks yang disebut indeks pasar saham. Indeks pasar saham merupakan indikator yang mencerminkan kinerja sahamsaham di pasar. Karena merupakan indikator yang menggambarkan pergerakan-pergerakan harga-harga saham, maka indeks pasar saham juga disebut indeks harga saham (Tandelilin 2010). 


\section{Ekspektasi Investor dan Informasi}

Investor dalam melakukan investasi tidak saja hanya mempergunakan estimasi atas prospek instrument investasi, tetapi factor psikologi sudah ikut menentukan investasi tersebut (Manurung, 2012). Ekspektasi investor dalam psikologi dapat dijelaskan dengan teori Prospect theory dan Rational Expectation.

Kahnenan \& Tversky ( 1979) dalam Hidayat ( 2010 ) menyatakan bahwa manusia dalam hal ini investor memberikan bobot keputusan yang berbeda dalam situasi mendapatkan keuntungan dan kerugian. Beban psikologis investor dalam kondisi kerugian jauh lebih berat dibandingkan dengan emosi positif investor dalam kondisi mendapatkan keuntungan, sekalipun kerugian atau keuntungan tersebut dalam jumlah yang sama. Karena itu investor lebih bersikap menghindari kerugian daripada menghindari resiko atau dengan kata lain dalam situasi mendapatkan keuntungan investor cenderung menghindari resiko, demikian juga sebaliknya, dalam situasi yang merugi orang lebih mengambil resiko. Selain hal tersebut teori ini juga menunjukkan adanya fenomena yang disebut framing effect. Keputusan investor dipengaruhi oleh isi dan cara informasi tersebut disampaikan. Sebagai contoh suatu informasi dapat sesuatu bisa disampaikan sebagai peluang untuk mendapatkan keuntungan atau sebagai kemungkinan kehilangan opportunity (menciptakan kerugian). Investor cenderung akan bertindak ketika informasi yang disampaikan sebagai kehilangan opportunity (menciptakan kerugian).

Ekspektasi investor juga dapat dijelaskan dengan teori Rational Expectation yang disampaikan oleh Sheffrin. Menurut Sheffrin dalam Sumani (2008) ekspektasi dibentuk dengan menggunakan semua informasi yang ada. Dengan informasi yang ada investor dapat mengubah ekspektasi yang berdasarkan data historis tentang kondisi ekonomi masa depan.

Informasi dalam pasar modal dikenal dengan hipotesis efisiensi pasar. Pasar yang efisien adalah pasar dimana harga semua saham yang diperdagangkan telah mencerminkan semua informasi yang tersedia, sehingga hipotesis pasar efisien adalah pada pasar yang efisien dimana harga saham terevaluasi dengan cepat oleh informasi penting yang berkaitan dengan saham tersebut (Tandelilin, 2010). Fama (1970) dalam Tandelilin (2010) serta Bodie et al (2011) mengklasifikasikan bentuk pasar yang efisien ke dalam tiga efficient market hypothesis (EMH) 138 yaitu efisien dalam bentuk lemah (weak form), efisien dalam bentuk setengah kuat (semi strong) dan efisiensi dalam bentuk kuat (strong form). Ketiga jenis efficient market hypothesis (EMH) dapat digambarkan dalam gambar II.

Efisiensi pasar dalam bentuk lemah (weak form) berarti semua informasi dimasa lalu akan tercermin dalam harga yang terbentuk sekarang.

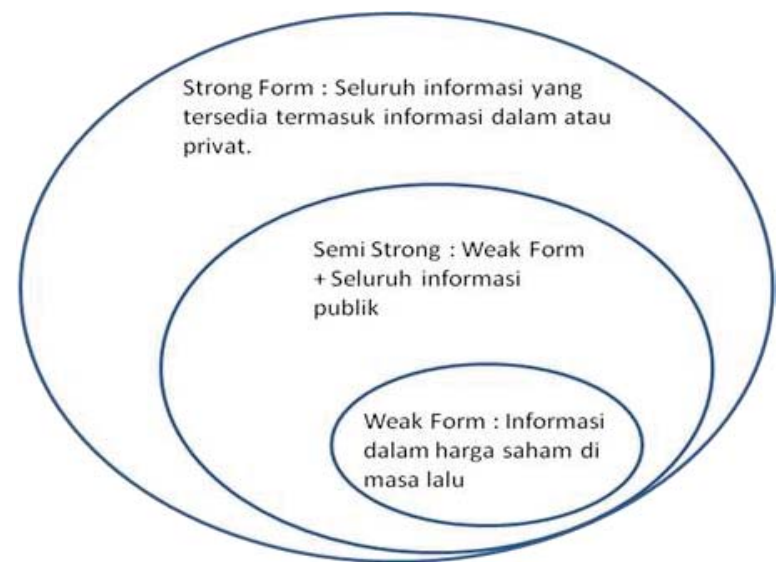

Gambar 2. Klasifikasi Efficient Market
Hypothesis (EMH)

Sumber : Tendelilin (2010) dimodifikasi penulis

Oleh karena itu harga masa lampau tersebut tidak dapat lagi dipergunakan untuk memperkirakan perubahan dimasa mendatang karena sudah tercermin pada harga masa sekarang. Akibatnya adalah investor tidak akan dapat memperkirakan nilai pasar saham dimasa mendatang dengan mempergunakan data masa lampau (Tandelilin, 2010; Bodie et al, 2011)

Efisiensi pasar dalam bentuk setengah kuat (semi strong) berarti harga pasar yang terbentuk sekarang telah mencerminkan informasi masa lampau ditambah dengan semua informasi yang dipublikasikan. Pada pasar efisien bentuk setengah kuat, return tak normal hanya terjadi di seputar pengumuman suatu peristiwa sebagai representasi dari respons pasar terhadap pengumuman tersebut. Suatu pasar dinyatakan efisien dalam bentuk setengah kuat bila informasi terserap atau direspons dengan cepat oleh pasar. Return tak normal yang terjadi berkepanjangan mencerminkan sebagian respon pasar terlambat dalam menyerap atau menginterpretasi informasi dan dengan demikian dianggap pasar tidak efisien dalam bentuk setengah kuat (Tandelilin, 2010; Bodie et al, 2011).

Efisiensi pasar dalam bentuk kuat (strong form) berarti pasar saham yang terbentuk 
sekarang telah mencerminkan informasi masa lampau ditambah informasi yang dipublikasikan ditambah informasi yang tidak dipublikasikan. Pada pasar efisien bentuk kuat tidak akan ada seorang investor pun yang dapat memperoleh return tidak normal (Tandelilin, 2010 ; Bodie et al, 2011).

\section{Ekspektasi Investor, Survey Ekspektasi} Kegiatan Usaha dan Perumusan Hipotesis Seperti sudah dibahas sebelumnya bahwa nilai intriksik saham merupakan prediksi aliran kas masuk dimasa depan berupa deviden. Laba perusahaan tergantung dari kondisi perusahaan dan kondisi eksternal perusahaan dimasa mendatang. Salah satu cara mengetahui informsi dimasa mendatang adalah melaksanakan survey tentang kenyakinan pelaku ekonomi tentang keadaan dimasa mendatang.

Bank Indonesia sejak triwulan I tahun 1993 melaksanakan survei Kegiatan Dunia Usaha, jumlah responden mencapai 2.868 perusahaan yang tersebar di seluruh wilayah Indonesia secara purposive sampling. Hasil survey ada beberapa jenis yaitu kegiatan usaha, kapasitas produksi, kondisi keuangan dan akses kredit, tenaga kerja, harga jual, inflasi, investasi, kinerja sektor industri pengolahan, situasi bisnis tiga bulan mendatang dan enam bulan mendatang. Dalam penelitian ini diambil hasil survey yang akan mempengaruhi laba perusahaan pada masa sekarang dan akan datang yaitu ekspektasi terhadap kegiatan usaha pada masa sekarang, kondisi keuangan (arus kas) pada masa sekarang, kemudahan akses kredit pada masa sekarang, ekspektasi situasi bisnis pada tiga bulan mendatang dan enam bulan mendatang.

Kelima ekspektasi kegiatan usaha terkait dengan pendapatan perusahaan, laba dan harga saham dapat diuraikan sebagai berikut :

1.Ekspektasi terhadap kegiatan usaha sekarang

Jika ekspektasi kegiatan usaha masa sekarang optimistik, perusahaan diekspektasikan dapat beroperasi dengan baik. Jika perusahaan dapat beroperasi baik diharapkan penjualan naik, sehingga laba perusahaan juga akan bertambah yang mengakibatkan deviden yang akan dibayarkan juga bertambah. Dengan naiknya deviden maka aliran kas masuk ke investor akan meningkat yang mengakibatkan nilai intriksik saham saat sekarang juga akan meningkat. Jika nilai saham meningkat maka harga saham akan meningkat dan jika harga saham secara umum meningkat maka indeks harga saham gabungan juga akan meningkat. Demikian juga jika ekspektasi terhadap kegiatan usaha masa sekarang memburuk, maka harga saham dapat turun dan jika secara umum harga saham turun maka indeks harga saham gabungan juga akan turun.

\section{Ekspektasi kondisi keuangan sekarang}

Survei Bank Indonesia salah satunya adalah untuk menilai ekspektasi kondisi keuangan perusahaan khususnya arus kas. Jika ekspektasi arus kas masa sekarang optimistik, perusahaan diekspektasikan dapat beroperasi dengan baik. Jika perusahaan beroperasi dengan didukung oleh arus kas yang baik diharapkan penjualan naik, karena perusahaan akan banyak memberi kemudahan kepada pelanggan maupun pemasoknya sehingga mendapatkan harga yang terbaik dan mengakibatkan penjualan naik. Jika penjualan naik dan bahan baku dapat diperoleh dengan harga yang lebih kompetitif maka biaya akan turun sehingga penggabungan efek dari kenaikan penjualan dan penurunan biaya mengakibatkan laba perusahaan juga akan naik yang akhirnya deviden yang dibayarkan juga bertambah. Dengan naiknya deviden maka aliran kas masuk ke investor akan meningkat yang mengakibatkan nilai intriksik saham saat sekarang juga akan meningkat, jika nilai saham meningkat maka harga saham akan meningkat. Penelitian Vakilifard dan Shahmoradi (2014) serta Ernayani dan Robiyanto (2016) mengkonfirmasi hal tersebut dan menemukan bukti empiris bahwa arus kas berpengaruh terhadap return saham. Akhirnya secara umum jika hargaharga saham meningkat maka indeks harga saham gabungan juga akan meningkat. Demikian juga jika ekspektasi kondisi keuangan terutama arus kas perusahaan memburuk, maka harga saham dapat turun dan jika secara umum harga saham turun maka indeks harga saham gabungan juga akan turun.

\section{Ekspektasi kemudahan akses kredit.}

Struktur keuangan atau struktur pendanaan suatu perusahaan merupakan komposisi dari modal dari pemilik, laba ditahan dan hutang. Keputusan struktur keuangan perusahaan 
tergantung pada tingkat pertumbuhan penjualan, stabilitas arus kas, karakteristik industri, struktur asset, sikap manajemen dan sikap pemberi pinjaman (Weston \& Copeland, 1997). Akses kemudahan kredit merupakan sikap pemberi pinjaman akan mempengaruhi keputusan terhadap struktur keuangan yang akan diambil oleh manajemen, karena menyangkut leverage keuangan, karena hutang akan menaikkan tingkat resiko hasil pengembalian kepada pemegang saham dan sering kali menaikkan juga tingkat hasil pengembalian kepada pemegang saham (Weston \& Copeland, 1997). Optimasi yang baik dalam struktur keuangan antara setoran dari pemilik, laba di tahan dan hutang akan mempengaruhi terhadap biaya modal dan pajak yang akhirnya akan mempengaruhi nilai perusahaan. Jika nilai perusahaan tinggi maka nilai sahamnya juga akan tinggi dan sebaliknya. Namun kajian teoritis tersebut dapat berbeda pada pembuktian empiris di penelitian, seperti penelitian Gunarso (2014) yang mengkaji pengaruh leverage terhadap harga saham di Bursa Efek Indonesia menemukan bukti empiris bahwa leverage tidak berpengaruh terhadap harga saham.

\section{Ekspektasi situasi bisnis mendatang}

Operasi perusahaan akan dipengarui lingkungan eksternal perusahaan, baik lingkungan makro yang terdiri dari politik, ekonomi, tekhnologi, lingkungan dan hukum serta lingkungan industri,dimana perusahaan akan mendapat tekanan kompetitifnya dari pesaing lama, pesaing baru, produksi substitusi, pemasok dan pelanggannya (Thompson, et al., 2012). Kondisi lingkungan eksternal tersebut yang akan mempengaruhi situasi bisnis. Jika situasi bisnis baik maka perusahaan akan beroperasi dengan baik dan jika situasi buruk maka perusahaan akan beroperasi sebaliknya. Situasi bisnis masa mendatang akan mempengaruhi kemampulabaan perusahaan dan akan mempengaruhi tingkat kompepetitif perusahaan dibandingkan dengan pesaingnya dimata pelanggan dan calon pelanggannya. Harga saham masa sekarang mencerminkan ekspektasi masa mendatang dan hal tersebut menunjukkan bahwa investasi saham adalah future oriented business. Sehingga situasi bisnis masa mendatang akan mempengaruhi harga saham masa sekarang.

Kajian teoritis tersebut terkonfirmasi hasil penelitian Campbell dan Diebold (2007) yang menemukan bukti empiris bahwa kondisi ekspektasi bisnis berpengaruh terhadap abnormal return saham. Demikian juga penelitian Pinho dan Madaleno (2011) yang menemukan bukti empiris bahwa kepercayaan bisnis berpengaruh terhadap evolusi pasar saham.

Bank Indonesia dalam melaksanakan survey membagi ekspektasi situasi bisnis ini menjadi dua yaitu ekspektasi bisnis tiga bulan mendatang dan enam bulan mendatang.

Berdasarkan uraian tersebut diatas, maka dapat dirumuskan hipotesis sebagai berikut :

$\mathrm{H}_{1}$ : Ekspektasi kegiatan usaha masa sekarang berpengaruh positif signifikan terhadap pergerakan indeks harga saham gabungan.

$\mathrm{H}_{2}$ : Ekspektasi kondisi keuangan perusahaan masa sekarang berpengaruh positif signifikan terhadap pergerakan indeks harga saham gabungan.

$\mathrm{H}_{3}$ : Ekspektasi kemudahan akses kredit masa sekarang berpengaruh signifikan terhadap pergerakan indeks harga saham gabungan.

$\mathrm{H}_{4}$ : Ekspektasi situasi bisnis tiga bulan kedepan berpengaruh positif signifikan terhadap pergerakan indeks harga saham gabungan.

$\mathrm{H}_{5}$ : Ekspektasi situasi bisnis enam bulan kedepan berpengaruh positif signifikan terhadap pergerakan indeks harga saham gabungan.

H6: Ekspektasi kegiatan usaha, kondisi keuangan perusahaan dan kemudahan akses kredit masa sekarang, ekspektasi situasi bisnis tiga dan enam bulan kedepan secara bersama-sama berpengaruh positif signifikan terhadap pergerakan indeks harga saham gabungan.

\section{METODOLOGI PENELITIAN}

\section{Data}

Penelitian ini mempergunakan data indeks harga saham gabungan setelah penyesuaian Bursa Efek 
Indonesia yang disajikan dalam Webiste Yahoo Finance: http://yahoo.finance.com dan hasil survey Bank Indonesia tentang Kegiatan Dunia Usaha mulai triwulan I tahun 2002 sampai dengan triwulan III tahun 2016.

Cakupan dunia usaha dalam survey Bank Indonesia adalah perusahaan yang bergerak dalam sektor-sektor sebagai berikut:

1.Pertanian, perkebunan, peternakan, kehutanan dan perikanan.

2.Pertambangan dan penggalian

3.Industri Pengolahan

4.Listrik, Gas dan Air bersih

5.Kontruksi

6.Perdagangan, Hotel dan Restoran

7.Pengangkutan dan Kontruksi

8.Keuangan, Real estate dan Jasa Perusahaan

9.Jasa-jasa.

Survei Kegiatan Dunia Usaha yang dilakukan oleh Bank Indonesia dengan metode purposive sampling dengan responden mencapai 2.868 perusahaan tersebar di seluruh Indonesia. Secara statistik sample memiliki sampling error sebesar $2 \%$ pada taraf signifikansi $\alpha=5 \%$

\section{Definisi Operasi dan Pengukuran Variabel}

1.Perubahan Indeks Harga Saham Gabungan Perubahan Indeks Harga Saham Gabungan (RIHSG) adalah perubahan IHSG setelah adjustment di Bursa Efek Indonesia rata-rata tiga bulanan (periode) t. Pengukuran variabel dengan formulasi: RIHSGt = (IHSGt - IHSGt-1) / IHSGt-1

2.Ekspektasi kegiatan usaha masa sekarang, yaitu berdasarkan saldo bersih tertimbang (SBT - weighted net balance) yang diperoleh dari hasil perkalian saldo bersih sektor/subsektor yang bersangkutan dengan bobot sektor/subsektor yang bersangkutan sebagai penimbangnya berdasarkan survei Kegiatan Dunia Usaha oleh Bank Indonesia setiap triwulanan (periode) t. Pengukuran variabel mengambil nilai saldo bersih (SBT - weighted net balance) dengan formulasi : $\mathrm{SBT}=(\%$ Jawaban Meningkat - \% Jawaban Menurun) $\mathrm{x}$ bobot sektor/subsektor.

3.Ekspektasi kondisi keuangan masa sekarang, yaitu berdasarkan saldo bersih (SB-net balance) survei Kegiatan Dunia Usaha oleh Bank Indonesia setiap triwulanan (periode) t. Pengukuran variabel mengambil nilai saldo bersih (SB-net balance), dengan formulasi : SB-net balance $=(\%$ Jawaban Meningkat - \% Jawaban Menurun)
4.Ekspektasi kemudahan akses kedit masa sekarang, yaitu berdasarkan saldo bersih (SB-net balance) survei Kegiatan Dunia Usaha oleh Bank Indonesia setiap triwulanan (periode) t. Pengukuran variabel mengambil nilai saldo bersih (SB-net balance) dengan formulasi: SB-net balance $=(\%$ Jawaban Meningkat - \% Jawaban Menurun)

5.Ekspektasi situasi bisnis tiga bulan kedepan, yaitu berdasarkan saldo bersih tertimbang (SBT-weighted net balance) yang diperoleh dari hasil perkalian saldo bersih sektor/subsektor yang bersangkutan dengan bobot sektor/subsektor yang bersangkutan sebagai penimbangnya berdasarkan survei Kegiatan Dunia Usaha oleh Bank Indonesia setiap triwulanan (periode) t. Pengukuran variabel mengambil nilai saldo bersih tertimbang (SBT-weighted net balance) dengan formulasi: SBT-weighted net balance $=(\%$ Jawaban Meningkat $-\%$ Jawaban Menurun) x bobot sektor/subsektor. Dalam laporan Survei Kegiatan Dunia Usaha Bank Indonesia, mulai tahun 2014 tidak tersaji ekspektasi situasi bisnis tiga bulan kedepan, maka data tersebut diproksikan dengan hasil nilai saldo bersih tertimbang (SBT-weighted net balance) Perkiraan Kegiatan Usaha. Sebagai misal nilai saldo bersih survey Ekspektasi Situasi Bisnis triwulan I tahun 2014 akan diambilkan dari saldo bersih tertimbang (SBT - weighted net balance) Perkiraan Kegiatan Usaha triwulan II tahun 2014.

6.Ekspektasi situasi bisnis enam bulan kedepan, yaitu berdasarkan saldo bersih tertimbang (SBT -weighted net balance) yang diperoleh dari hasil perkalian saldo bersih sektor/subsektor yang bersangkutan dengan bobot sektor/subsektor yang bersangkutan sebagai penimbangnya berdasarkan surveyi Kegiatan Dunia Usaha oleh Bank Indonesia setiap triwulanan (periode) t. Pengukuran variabel mengambil nilai saldo bersih tertimbang (SBT-weighted net balance) dengan formulasi: SBT- weighted net balance $=(\%$ Jawaban Meningkat - $\%$ Jawaban Menurun) x bobot sektor/subsektor. Dalam laporan Survei Kegiatan Dunia Usaha Bank Indonesia, mulai tahun 2014 tidak tersaji ekspektasi situasi bisnis enam bulan kedepan, maka data tersebut diproksikan dengan hasil nilai saldo bersih tertimbang (SBT -weighted net 
balance) Perkiraan Kegiatan Usaha. Sebagai misal nilai saldo bersih survei Ekspektasi Situasi Bisnis triwulan I tahun 2014 akan diambilkan dari saldo bersih tertimbang (SBT - weighted net balance) Perkiraan Kegiatan Usaha triwulan III tahun 2014.

\section{Model Pengujian Hipotesis}

Pengujian hipotesis dengan model regresi berganda sebagai berikut :

$\mathrm{RIHSG}_{\mathrm{t}}=\beta_{0}+\beta_{1} \mathrm{KU}_{\mathrm{t}}+\beta_{2} \mathrm{KK}_{\mathrm{t}}+\beta_{3} \mathrm{AK}_{\mathrm{t}}+\beta_{4} \mathrm{ST}_{\mathrm{t}}+$ $\beta_{5} \mathrm{SE}_{\mathrm{t}}+\varepsilon$

Dimana :

RIHSG $_{\mathrm{t}}$ : Perubahan IHSG pada periode t.

$\beta_{0}: \quad$ Konstanta

$\beta_{1}-\beta_{5}$ : Nilai koefisien regresi

$\mathrm{KU}_{\mathrm{t}}$ : $\quad$ Ekspektasi Kegiatan Usaha periode $\mathrm{t}$.

$\mathrm{KK}_{\mathrm{t}}$ : Ekspektasi Kondisi Keuangan periode $\mathrm{t}$.

$\mathrm{AK}_{\mathrm{t}}: \quad$ Ekspektasi Akses Kredit periode t.

$\mathrm{ST}_{\mathrm{t}}$ : Ekspektasi Situasi Bisnis Tiga Bulan kedepan periode $\mathrm{t}$.

$\mathrm{SE}_{\mathrm{t}}$ : $\quad$ Ekspektasi Situasi Bisnis Enam Bulan kedepan periode $\mathrm{t}$.

ع: $\quad$ Error term.

\section{PEMBAHASAN}

Perkembangan Indeks Harga Saham Gabungan dan Ekspektasi Kegiatan Dunia Usaha Triwulan I 2000 S/D Triwulan III 2016

Indeks Harga Saham Gabungan (IHSG) Bursa Efek Indonesia selama jangka waktu penelitian, nilai terendah pada indeks 462 pada triwulan I tahun 2002 dan tertinggi pada triwulan I tahun 2015 dengan indeks 5.419. Terjadi trend penurunan pada tahun 2008 dan fluktuasi pada tahun 2013 sampai dengan 2016. Trend IHSG tergambar dalam gambar 3

Perubahan indeks IHSG tertinggi pada tahun 2008 dengan fluktuasi yang tinggi pula dan terendah pada tahun 2005 dan 2011. Fluktuasi perubahan indeks tergambar dalam gambar 3.

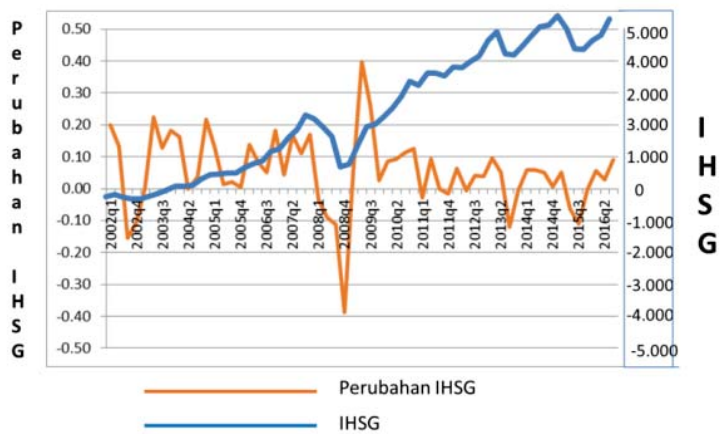

Gambar 3. Trend IHSG dan Perubahan Indeks

IHSG Triwulan I 2002 s/d Triwulan III 2016 142
Sumber : Data dari Yahoo Finance. Penyajian grafik oleh penulis

Berdasarkan gambar 4 tergambar bahwa selama periode penelitian, pada tahun 2002 sampai dengan 2013 trend kegiatan usaha masa sekarang, situasi bisnis tiga bulan dan enam bulan mendatang fluktuasinya sangat tajam dan mulai tahun 2014 sampai dengan 2016 fluktuasinya rendah meskipun rata-ratanya dibawah rata-rata periode sebelumnnya. Dalam laporan Survei Kegiatan Dunia Usaha Bank Indonesia, mulai tahun 2014 tidak tersaji ekspektasi situasi bisnis tiga dan enam bulan kedepan, maka data tersebut diproksikan dengan hasil nilai saldo bersih tertimbang (SBT weighted net balance) Perkiraan Kegiatan Usaha. Sebagai misal nilai saldo bersih survey Ekspektasi Situasi Bisnis triwulan I tahun 2014 akan diambilkan dari saldo bersih tertimbang (SBT - weighted net balance) Perkiraan Kegiatan Usaha riwulan II tahun 2014. Ketidaktersediaan data dan memakai proksi tersebut yang mengakibatkan trend mulai tahun 2014 berada dibawah rata-rata tahun sebelumnnya.

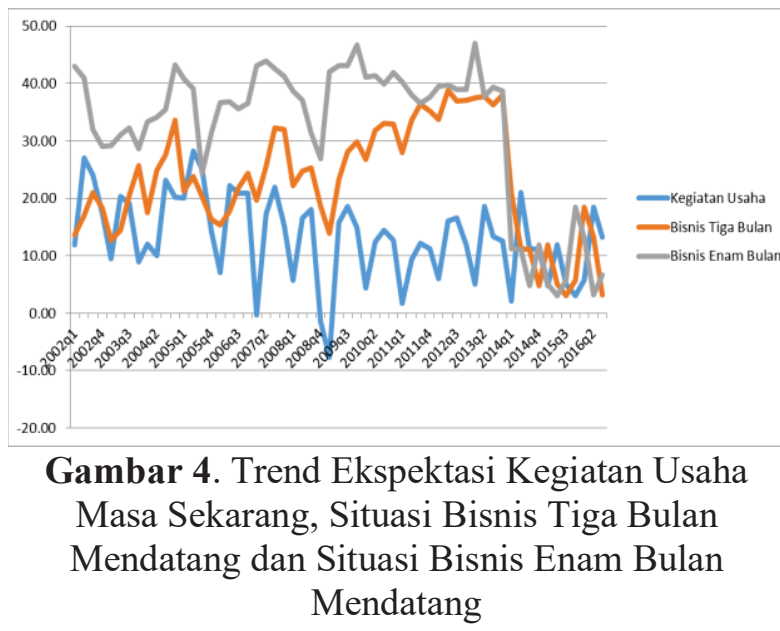

Sumber : Data dari hasil Survei Bank Indonesia. Pemilihan data dan penyajian grafik oleh penulis.

Trend ekspektasi kemudahan akses kredit terjadi penurunan selama kurun waktu tahun 2002 sampai dengan 2016, sedangkan trend ekspektasi kondisi keuangan pada periode tersebut mengalami peningkatan seperti tergambar dalam gambar 5 . 


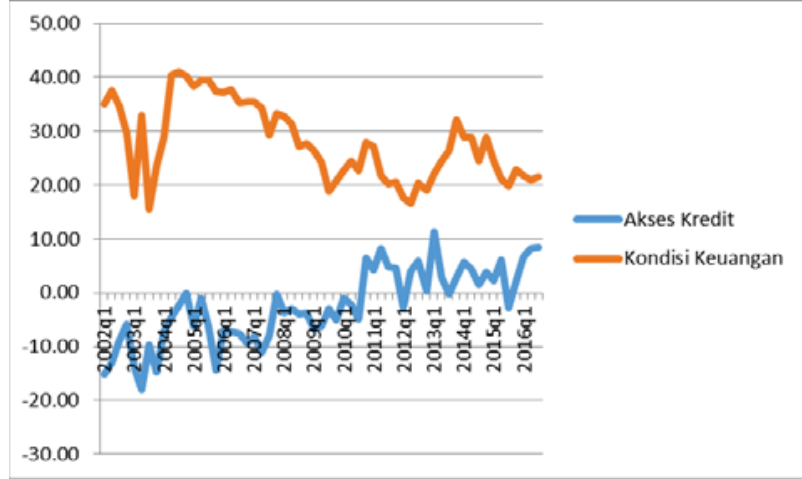

Gambar 5. Trend Ekspektasi Akses Kredit Masa Sekarang dan Kondisi Keuangan Masa Sekarang

Sumber : Data dari hasil Survei Bank Indonesia. Pemilihan data dan penyajian grafik oleh penulis.

\section{Uji Asumsi Klasik}

Supaya model regresi yang dipergunakan mendapatkan hasil yang baik, maka harus memenuhi syarat best linear unbiased estimator (blue) yaitu kondisi yang tidak mengandung multikolinearitas, heteroskedastitas dan autokrelasi. Hasil pengujian menunjukkan bahwa model tidak mengandung multikolinearitas, heteroskedastitas dan autokorelasi.

\section{Hasil Pengujian Hipotesis}

Hasil Pengujian hipotesis seperti dalam tabel sebagai berikut :

Tabel 2. Hasil Pengujian Hipotesis

\begin{tabular}{ccccccc}
\hline \multicolumn{3}{c}{ Hipotesis } & \multicolumn{4}{c}{ Hasil Pengujian Hipotesis } \\
\cline { 1 - 5 } No & \multirow{2}{*}{ Arah } & \multicolumn{2}{c}{ Arah } & \multicolumn{2}{c}{ Signifikansi } & \\
\cline { 3 - 6 } & & t-statistik & Tanda & Prob & Signifikansi & \\
\cline { 1 - 5 } H1 & + & 0.755738 & + & 0.4533 & Tidak signifikan & Tidak Terbukti \\
H2 & + & 1.75464 & + & 0.0853 & Signifikan $\alpha=10 \%$ & Terbukti \\
H3 & + - & -0.80522 & - & 0.4244 & Tidak signifikan & Tidak Terbukti \\
H4 & + & -1.714603 & - & 0.0925 & Signifikan $\alpha=10 \%$ & Tidak Terbukti \\
H5 & + & 1.992277 & + & 0.0517 & Signifikan $\alpha=10 \%$ & Terbukti \\
H6 & + & 2.614316 & + & 0.0275 & Signifikan $\alpha=5 \%$ & Terbukti \\
\hline
\end{tabular}

Sumber : Hasil Pengolahan Data

\section{Analisis}

Pengujian Hipotesis $\mathrm{H}_{1}$ : Ekspektasi kegiatan usaha sekarang berpengaruh positif signifikan terhadap pergerakan indeks harga saham gabungan.

Berdasarkan pengujian hipotesis menemukan bukti empiris bahwa ekspektasi kegiatan usaha sekarang berpengaruh positif namun secara statistik tidak signifikan. Dengan demikian hipotesis $\mathrm{H}_{1}$ ditolak.

Bukti empirik pengujian hipotesis diatas menunjukkan bahwa ekspektasi kegiatan usaha sekarang oleh pelaku usaha tidak penting, karena harga saham mencerminkan ekspektasi masa mendatang dan hal tersebut menunjukkan bahwa investasi saham adalah future oriented business. Nilai suatu intrinsik suatu saham merupakan present value dari deviden-deviden yang akan diterima oleh pemodal di kemudian hari (Husnan, 2005).

Pengujian Hipotesis $\mathrm{H}_{2}$ : Ekspektasi kondisi keuangan perusahaan sekarang berpengaruh positif signifikan terhadap pergerakan indeks harga saham gabungan. Berdasarkan pengujian hipotesis menemukan bukti empiris bahwa ekspektasi kondisi keuangan perusahaan masa sekarang berpengaruh positif dan secara statistik signikan terhadap pergerakan IHSG Bursa Efek Indonesia (BEI). Dengan demikian hipotesis $\mathrm{H}_{2}$ diterima.

Bukti empirik pengujian hipotesis diatas terkonfirmasi juga dengan hasil penelitian Vakilifard dan Shahmoradi (2014) serta Ernayani dan Robiyanto (2016) yang menemukan bukti empiris bahwa arus kas berpengaruh terhadap return saham, yang berarti berpengaruh terhadap harga saham dan jika terpengaruhnya tersebut adalah pada seluruh emiten maka akan menyebabkan pergerakan indeks harga saham gabungan.

\section{Pengujian Hipotesis $\mathrm{H}_{3}$ : $\quad$ Ekspektasi kemudahan akses kredit sekarang berpengaruh signifikan terhadap pergerakan indeks harga saham gabungan}

Berdasarkan pengujian hipotesis menemukan bukti empiris bahwa ekspektasi akses kredit masa sekarang berpengaruh negatif namun secara scara statistik tidak signikan terhadap IHSG Bursa Efek Indonesia (BEI). Dengan demikian hipotesis $\mathrm{H}_{3}$ ditolak.

Akses kemudahan kredit merupakan sikap pemberi pinjaman dan akan mempengaruhi keputusan terhadap struktur keuangan yang akan diambil oleh manajemen menyangkut leverage keuangan, karena hutang akan menaikkan tingkat resiko hasil pengembalian kepada pemegang saham dan sering kali menaikkan juga tingkat hasil pengembalian kepada pemegang saham (Weston \& Copeland, 1997). Optimasi yang baik dalam struktur keuangan antara setoran dari pemilik, laba di tahan dan hutang akan mempengaruhi terhadap biaya modal dan pajak yang akhirnya akan mempengaruhi 
nilai perusahaan. Jika nilai perusahaan tinggi maka nilai sahamnya juga akan tinggi dan sebaliknya. Namun penelitian ini menunjukkan bahwa ekspektasi kemudahan akses kredit berpengaruh negatif namun tidak signifikan.

Pengujian Hipotesis $\mathrm{H}_{4}$ : Ekspektasi situasi bisnis tiga bulan kedepan berpengaruh positif signifikan terhadap pergerakan indeks harga saham gabungan.

Berdasarkan pengujian hipotesis menemukan bukti empiris bahwa ekspektasi situasi bisnis tiga bulan kedepan berpengaruh negatif dan secara statistik signifikan terhadap pergerakan IHSG Bursa Efek Indonesia (BEI). Dengan demikian hipotesis $\mathrm{H}_{4}$ ditolak.

Hasil penelitian ini menunjukkan bahwa meskipun harga saham mencerminkan ekspektasi situasi bisnis masa mendatang, namun ekspektasi situasi bisnis jangka waktu tiga bulan kedepan akan berpengaruh negatif terhadap kinerja ISHG.

Pengujian Hipotesis $\mathbf{H}_{5}$ : Ekspektasi situasi bisnis enam bulan kedepan berpengaruh positif signifikan terhadap pergerakan indeks harga saham gabungan

Berdasarkan pengujian hipotesis menemukan bukti empiris bahwa ekspektasi situasi bisnis enam bulan kedepan berpengaruh positif dan secara statistik signifikan terhadap pergerakan IHSG Bursa Efek Indonesia (BEI). Dengan demikian hipotesis $\mathrm{H}_{5}$ diterima.

Hasil penelitian ini yang menunjukkan bahwa ekspektasi situasi bisnis enam bulan kedepan berpengaruh terhadat IHSG dan terkonfirmasi dengan penelitian Pinho dan Madaleno (2011) yang menemukan bukti empiris bahwa kepercayaan bisnis berpengaruh terhadap evolusi pasar saham.

Pengujian Hipotesis $\mathrm{H}_{6}$ : Ekspektasi kegiatan usaha sekarang, kondisi keuangan sekarang dan kemudahan akses kredit sekarang, ekspektasi situasi bisnis tiga dan enam kedepan berpengaruh positif signifikan terhadap pergerakan indeks harga saham gabungan.

Berdasarkan pengujian hipotesis menemukan bukti empiris bahwa ekspektasi kegiatan usaha sekarang, kondisi keuangan sekarang dan kemudahan akses kredit sekarang, ekspektasi situasi bisnis tiga dan enam kedepan berpengaruh positif dan secara statistik signifikan terhadap pergerakan IHSG Bursa Efek Indonesia (BEI). Dengan demikian hipotesis $\mathrm{H}_{6}$ diterima.

Hasil penelitian ini menunjukkan bahwa jika ekspektasi kegiatan usaha masa sekarang dan masa mendatang optimistik, perusahaan diekpektasikan dapat beroperasi dengan baik yang akan membuat harga saham meningkat dan secara umum akan meningkatkan indeks harga saham gabungan. Demikian juga sebaliknya jika ekspektasi usaha kebalikannya. Hasil penelitian ini terkonfirmasi dengan hasil penelitian Campbell dan Diebold (2007) yang menemukan bukti empiris bahwa kondisi ekspektasi bisnis berpengaruh terhadap abnormal return saham. Demikian juga terkonfirmasi dengan penelitian Pinho dan Madaleno (2011) yang menemukan bukti empiris bahwa kepercayaan bisnis berpengaruh terhadap evolusi pasar saham.

\section{KESIMPULAN}

Berdasarkan pengujian hipotesis menemukan bukti empiris bahwa variabel ekspektasi kondisi keuangan perusahaan waktu sekarang dan ekspektasi situasi bisnis enam bulan kedepan berpengaruh positif signifikan terhadap IHSG serta ekspektasi situasi bisnis tiga bulan kedepan berpengaruh negatif signifikan terhadap IHSG. Variabel ekspektasi kegiatan usaha sekarang dan ekspektasi kemudahan akses kredit berpengaruh tidak signifikan terhadap IHSG. Seluruh variabel ekspektasi kegiatan usaha secara bersama-sama berpengaruh secara signifikan terhadap IHSG.

Berdasarkan kesimpulan tersebut diatas maka dapat direkomendasikan kepada investor bahwa secara umum ekspektasi kegiatan dunia usaha mempengaruhi pergerakan IHSG, maka pada waktu berinvestasi saham saat ini dapat mengamati pola tingkat ekspektasi kegiatan dunia usaha. Jika ekspektasi kegiatan dunia usaha menunjukkan kelima variabel optimistis, maka dapat diprediksi bahwa IHSG akan meningkat dan jika menunjukkan bahwa ekspektasi kondisi keuangan perusahaan sekarang dan ekspektasi situasi bisnis enam bulan kedepan juga optimistis, maka dapat diperkirakan bahwa IHSG juga akan meningkat. Kemudian investor dapat melakukan proses seleksi ditingkat detail saham dari sektor usaha dan emiten yang akan dipilih.

\section{REFERENSI}

Bank Indonesia. (2016). Survei Kegiatan Dunia Usaha Triwulan III-2016. Departemen Statistik, Divisi Statitistik, Sektor Riel 
Bank Indonesia. Diterbitkan secara online dalam : http://www.bi.go.id/id/publikasi/survei/k egiatan-duniausaha/Pages/SKDU_TRIWULAN3_2016.aspx. Diakses tanggal 15 Maret 2017

Bank Indonesia. (2014). Survei Kegiatan Dunia Usaha Triwulan IV-2013. Departemen Statistik, Divisi Statitistik, Sektor Riel Bank Indonesia. Diterbitkan secara online dalam : http://www.bi.go.id/id/publikasi/survei/k egiatan-dunia-usaha/Pages/Triwulan-IV2013.aspx. Diakses tanggal 19 Maret 2017

Bank Indonesia. (2013). Survei Kegiatan Dunia Usaha Triwulan IV-2012. Departemen Statistik Ekonomi dan Moneter, Divisi Statitistik Sektor Riel Bank Indonesia. Diterbitkan secara online dalam: http://www.bi.go.id/id/publikasi/survei/k egiatan-duniausaha/Pages/skdu tw412.aspx. Diakses tanggal 15 Maret 2017

Bank Indonesia. (2011). Survei Kegiatan Dunia Usaha Triwulan IV-2010. Departemen Statistik Ekonomi dan Moneter, Divisi Statitistik Sektor Riel Bank Indonesia. Diterbitkan secara online dalam: http://www.bi.go.id/id/publikasi/survei/k egiatan-duniausaha/Pages/skdu tw0410.aspx. Diakses tanggal 15 Maret 2017

Bank Indonesia. (2007). Survei Kegiatan Dunia Usaha Triwulan IV-2006. Bagian Pengelolaan dan Pengembangan Data \& Informasi, Direktorat Statistik Ekonomi dan Moneter Bank Indonesia. Diterbitkan secara online dalam: http://www.bi.go.id/id/publikasi/survei/k egiatan-duniausaha/Pages/skdu_tw406.aspx. Diakses tanggal 15 Maret 2017

Bank Indonesia. (2004). Survei Kegiatan Dunia Usaha Triwulan IV-2003. Bagian Pengelolaan dan Pengembangan Data \& Informasi, Direktorat Statistik Ekonomi dan Moneter Bank Indonesia. Diterbitkan secara online dalam: http://www.bi.go.id/id/publikasi/survei/k egiatan-duniausaha/Pages/SKDU\%20TRiwulan\%20I V\%202003.aspx. Diakses tanggal 15 Maret 2017
Bodie, Z. Kane, A. \& Marcus, A. J. (2011). Investment and Portfolio Management, New York: McGraw-Hill/Irwin

Brealy, R. A., Myes, S. C., \& Allen, F. (2011). Priciple of Corporate Finance. Tenth Edition. New York: McGraw-Hill

Bolten, S. E., \&Weigand, R. A. (2000). The Generation of Stock Market Cycles dalam Bolten, S.E. 2000. Stock Market Cycles, A Practical Explanation, Quorum Books, Westport.

Campbell, S.D., \& Diebold, F.X. (2005). Stock Returns and Expected Business Conditions : Half a Century of Direct Evidence. NBER Working Paper No. 11736. November 2005. JEL No. G12. National Bureau of Economic Research. 1050 Massachusetts Avenue Cambridge, MA 02138. http://www.nber.org/papers/w11736. Diakses dari http.//www.ssc.upenn.edu tanggal 14 April 2014.

Cohen, D. A., \& Zarowin, P. (2007). Earnings Management over the Business Cycle, New York University: Stern School of Business.

Ernayani, R., \& Robiyanto. (2016). The Effect of The Cash Flows, Gross Profit and Company Size on The Indonesian Stock Returns (A Study on Basic and Chemical Industry Companies During the Periods of 2009-2014). IJABER, 14(1)

Gunarso, P. (2014). Laba Akuntansi, Leverage dan Ukuran Perusahaan Terhadap Harga Saham di Bursa Efek Indonesia. Jurnal Keuangan dan Perbankan, 18(1)

Hidayat, R. (2010). Relevansi Psikologi Ekonomi dalam 50 Tahun Himpunan Psikologi Indonesia (HIMPSI) : Redefinisi Psikologi Indonesia dalam Keberagaman. Jakarta: Penerbit Himpunan Psikologi Indonesia

Husnan, S. (2005). Dasar-Dasar Teori Portofolio dan Analisis Saham, UPP. AMP. Yogyakarta: YKPN

Mankiw, N.G. (2007). Makroekonomi. Edisi Keenam. Jakarta: Penerbit Erlangga

Manurung, A.H. (2012). Teori Investasi: Konsep dan Empiris. Jakarta: PT Adler Manurung Press

Pinho, C., \& Madaleno, M. (2011). On The Influence of Expectations Over International Stock Returns and Macroeconomic Variables. International Review of Accounting Banking and 
Finance,

$3(2)$,

Summer, http://www.irabf.org/publication/3On\%2 0 the $\% 20$ influence $\% 20$ of $\% 20$ expectation s\%20over\%20international $\% 20$ stock $\% 2$ 0returns\%20and $\% 20$ macroeconomic $\% 2$ 0variables.pdf. Diakses tanggal 14 April 2017.

Samuelson, P. A., \& Nordhaus, W. D. (1992). Makro Ekonomi. Terjemahan Edisi 14. Jakarta: Penerbit Erlangga

Sumani. (2008). Indeks Harga Saham Sebagai Leading Indicator Perekonomian Indonesia. Tesis Tidak Dipublikasikan. Program Magister Manajemen, Fakultas Ekonomi Universitas Indonesia Jakarta

Sumarsono. (2014). Pengaruh Ekspektasi Konsumen Terhadap Indeks Harga Saham Gabungan Di Bursa Efek Indonesia. Seminar dan Call For paper Forum Manajemen Indonesia (FMI) ke 6. Fakultas Ekonomi dan Bisnis Universitas Sumatera Utara. Medan.

Tandelilin, E. (2010). Protofolio dan Investasi, Teori dan Aplikasi, Edisi Pertama. Yogyakarta: Penerbit Kanisius
Thompson, A. A., Peteraf, M. A., Gamble, J. E., \& Strickland, A. J. (2012). Crafting and Executing Strategy, The Quest for Competitive Advantage, Concepts and Cases. Eighteenth Edition. New York: McGraw-Hill

Vakilifard, H. R., \& Sharmoradi, N. (2014). Investigating The Effects of Stable Profitability and Free Cash Flow on Stock Returns Companies Listed in Tehran Stock Excange. International Journal of Academic Research in Accounting, Finance and Management Sciences, 4(3). www.hrms.com. Diakses tanggal 14 April 2017.

Weston, J. F., \& Copeland, T. E. (1997). Manajemen Keuangan. Edisi Kesembilan. Terjemahan. Jakarta: Binarupa Aksara

Website Bank Indonesia : http://bi.go.id

Webiste Yahoo Finance $\mathrm{http}: / /$ yahoo.finance.com. 